\title{
Editorial
}

\section{At Last?}

In forty years of fighting for Sports Medicine, BASM has tried alone and tried with others. We co-founded one Institute in the sixties, which got nowhere, another in the nineties. We initiated Britain's lecture programmes, but Academe wasn't interested. That peculiarly British triad of inertia, prejudice and conservatism denied both athlete and doctor.

Society changed, medicine subtly slid from disease towards fitness. We sought specialist training and recognition, with jobs in reputable institutions for the new generation. We hoped to end our outcast phase as a specialty synonymous with embrocation and adverts in changing rooms.

'If 'sports medicine' is to avoid becoming the Pandora's Box of medicine, it is essential to counterbalance quackery with the responsible study and development of safe and reputable sports medicine practice. In all other branches of medicine this means academic, institutional and governmental recognition - why not in sports medicine? ${ }^{1 \prime}$

We recognized the need for external academic validation, hence mere certificates of attendance at our courses. Eventually the Society of Apothecaries initiated a public diploma in sports medicine and others followed. However,

The problem is that all these (British sports medicine) diplomas tread a narrow path between specialist and generalist knowledge and expertise. Inevitably, they do not represent completion of training or specialist status. ${ }^{2 s}$

So, despite a strong core of General Practice based diplomates and course attenders, nothing happened for aspiring specialists. Training and consultancy criteria were defined for other specialities, but the orphan sports medicine lagged behind on academic acceptance.

'While the Royal Colleges exist to promote the highest standards of medical practice, unfortunately they have, perhaps cynically and certainly selfishly, confined their interest in sports medicine to organizing examinations and extracting fees from self-taught enthusiasts while eschewing any responsible role in the practice, let alone the promotion, of the subject. ${ }^{3}$

This delayed introduction of the sort of universal standards for provision which were the hallmark of the pre-Thatcherite National Health Service.

'Failure to develop consultant services has encouraged proliferation of substandard clinics. ${ }^{4}$

It is tragic that 'sports medicine' has become associated with so many untrained self-promoting and self-appointed 'experts' in High Streets and stadia instead of properly trained and registered medical graduates supported by trained paramedics. Athletes became leisure age suckers for quacks. But - if doctors can't help patients, can we blame enthusiastic carers who lack knowledge, judgement and restraint in the face of such eager clients? We have been frustrated by lack of official support.

'We need now, within BASM, to define and express our criteria for professional training and recognition to avoid being represented by strangers to sports medicine or looking inadequate in direct comparison to the stringent criteria laid down for all other medical specialties. ${ }^{5}$

Perhaps the long dark night is over. The Royal Colleges, through the 'Conference of Medical Royal Colleges and their Faculties' is to consider initiating measures to advance and coordinate Sports Medicine. BASM has no place at this table and we may initially be represented by 'strangers to sports medicine'. In the best traditions of history, the coachmasters are climbing onto the bandwagon.

That BASM has played such a large part in getting the British bandwagon here should be a source of great pride to the Association. Now, the rules will be different. BASM faces fundamental challenges and will need radically to redefine itself. Its academic days may be numbered except in roles supporting a wider spectrum of academic developments ruled over by new regulatory bodies. The petty politics of proselytism may even be passé under the Collegiate steamroller.

We should rejoice in this de facto recognition of Sports Medicine. It should at last open the door to specialist careers. We must respond swiftly and constructively to ensure that any new structures do represent not just the inevitable 'strangers', but the working men and women of British Sports Medicine - the members of BASM.

\section{References}

Editorial. Corinth and Olympia. Br J Sports Med 1989; 23: 67-8.

Editorial. 'Sports Medicine - where are the specialists?' Br J Sports Med 1992; $26: 75$.

ibid.

Editorial. 'Sports Medicine on the line?' Br J Sports Med 1994; 28 : 3.

Editorial. 'BASM and the recognition of 'sports medicine'. Br J Sports Med 1994; 28 : 147. 